\title{
HUBUNGAN TINGKAT PENGETAHUAN IBU TENTANG STIMULASI PERKEMBANGAN DENGAN PERKEMBANGAN MOTORIK KASAR PADA ANAK USIA 1 - 5 TAHUN DI POSYANDU MEKARSARI NAYU TIMUR BANJARSARI
}

\author{
Oleh : \\ Ratna Indriati ${ }^{1}$,Wiga Ami Widyanto ${ }^{2}$, Anindya Dwi Pratiwi $^{3}$
}

\begin{abstract}
Abstrak
Introduction: Under five years of age is an important period of growth and development. One aspect is the development of gross motor skills in children. Gross motor development are not optimal can lead to decreased creativity in adapting. One of the factors that influence the development of children is the stimulation of the parents. From the initial survey in posyandu Mekarsari obtained two (2) children aged 19 months and 26 months have not been able to walk on his own and from the interview, mothers do not understand about the stimulation of growth in children.

The purpose: Of this study was to determine the relationship of the level of knowledge about stimulation of development with the development of gross motor in children aged 1-5 years in Posyandu Mekarsari Banjarsari.

Method: Correlation research design with cross sectional approach. Subjects were 66 mother and their children aged 1 - 5 years in Posyandu Mekarsari with sampling technique by simple random sampling. Data were obtained by questionnaire to determine the level of knowledge about stimulation of development and DDST tests to determine the gross motor development in children. The data obtained were analyzed with chi-square test with $p=0.05$

Results: Indicate the level of knowledge Capital on high category by 55 people (83.33\%) and moderate categories $11(16.67 \%)$, while children with gross motor development either as many as 47 children (71.21\%) and unfavorable developments 19 children (28.79\%). The results of the analysis using the chisquare test $p=0.005$ obtained so that the value of $p<0.05$, which means that $\mathrm{Ho}$ is rejected and $\mathrm{Ha}$ accepted.

The Conclusion: Of the research was there is relationship of the knowledge about stimulation of development with the development of gross motor in children aged 1-5 years in posyandu Mekarsari.
\end{abstract}

Keywords: Knowledge Level, stimulation of development, gross motor development

\section{PENDAHULUAN}

Masa anak di bawah lima tahun merupakan periode penting dalam tumbuh kembang anak karena pertumbuhan yang berlangsung pada masa balita akan mempengaruhi dan menentukan perkembangan anak selanjutnya.
(Gunawan, Fadlyana, dan Rusmil, 2011)

Salah satu aspek tumbuh kembang pada anak adalah motorik kasar. Kemampuan dari gerakan ini dipengaruhi oleh proses perkembangan kematangan organorgan tubuh anak itu sendiri. (Eveline dan Djamaludin, 2010) 
Tumbuh kembang dipengaruhi beberapa faktor, salah satunya adalah stimulasi yang diberikan. Apabila stimulasi yang diberikan secara baik, kontinyu, dan dengan segenap perasaan kasih sayang, tentunya akan mempengaruhi optimalisasi tumbuh kembang anak. Apalagi jika stimulasi dilakukan sejak dini, bervariasi, dan melibatkan sebanyak-banyaknya organ penginderaan anak. (Eveline dan Djamaludin, 2010)

Pengetahuan orang tua terutama pengetahuan ibu mengenai stimulasi perkembangan berpengaruh terhadap perkembangan anak. Pengetahuan ibu yang rendah mempunyai risiko untuk terjadinya keterlambatan perkembangan anak, disebabkan ibu belum tahu cara memberikan stimulasi perkembangan anaknya. (Gunawan, Fadlyana, dan Rusmil, 2011)

Posyandu Mekarsari Nayu Timur Kecamatan Banjarsari mempunyai balita sebanyak 80 balita, dari survei awal yang dilakukan didapatkan dari 4 (empat) balita yang datang ke posyandu ditemukan 2 (dua) balita usia 19 bulan dan 26 bulan belum bisa berjalan sendiri. Sedangkan menurut Soetjiningsih dan Ranuh (2014), anak seharusnya sudah mulai bisa melangkah tanpa berpegangan pada umur 12 bulan dan pada umur 19 - 20 bulan anak bisa loncat dengan satu kaki. Dari keempat ibu saat dilakukan wawancara menunjukkan 2 (dua) ibu masih belum memahami tentang stimulasi perkembangan.

Melihat latar belakang di atas maka penulis tertarik mengadakan penelitian mengenai "Hubungan Tingkat Pengetahuan lbu Tentang Stimulasi Perkembangan Dengan Perkembangan Motorik Kasar pada Anak Usia 1-5 Tahun di Posyandu Mekarsari Nayu Timur Kecamatan Banjarsari".

\section{METODE PENELITIAN}

Penelitian ini merupakan penelitian observasional analitik dengan metode cross sectional dan desain korelasi untuk mengetahui hubungan tingkat pengetahuan ibu tentang stimulasi perkembangan sebagai variabel bebas (independent variable) dengan perkembangan motorik kasar pada anak usia 1-5 tahun di Posyandu Mekarsari sebagai variabel terikat (dependent variable).

Populasi pada penelitian ini adalah seluruh ibu beserta anak balitanya di Posyandu Mekarsari yang berjumlah 80 orang. Sampel dalam penelitian ini adalah ibu beserta anak balitanya yang berjumlah 66 orang. Jumlah sampel ditentukan dengan berdasarkan tabel KRECJIE.

Teknik sampling penelitian adalah simple random sampling dengan sampel yang memenuhi kriteria inklusi yaitu ibu dengan anak usia 15 tahun yang bersedia menjadi responden dan kriteria eksklusi yaitu ibu dengan balita yang mengalami retardasi mental.

\section{HASIL PENELITIAN}

Penelitian dilakukan mulai bulan November 2014 - Februari 2015 di wilayah Posyandu Mekarsari Nayu Timur Banjarsari dengan jumlah responden sebanyak 66 ibu beserta anak balitanya. Pengumpulan data dengan menggunakan kuesioner dan formulir DDST.

1. Distribusi frekuensi tingkat pengetahuan ibu

Variabel tingkat pengetahuan terbagi dalam tiga kategori yaitu tingkat pengetahuan tinggi, tingkat pengetahuan sedang dan tingkat pengetahuan rendah. 
Tabel 1. Distribusi Frekuensi Tingkat Pengetahuan lbu tentang Stimulasi Perkembangan

\begin{tabular}{ccc}
\hline $\begin{array}{c}\text { Tingkat } \\
\text { Pengetahuan }\end{array}$ & $\mathrm{F}$ & $\%$ \\
\hline \hline Tinggi & 55 & $83,33 \%$ \\
Sedang & 11 & $16,67 \%$ \\
Rendah & 0 & 0 \\
\hline Jumlah & 66 & $100 \%$ \\
\hline
\end{tabular}

Dari tabel di atas dapat dicermati bahwa sebagian besar responden memiliki tingkat pengetahuan tinggi yaitu sebanyak 55 orang (83,33\%), 11 responden $(16,67 \%)$ dengan tingkat pengetahuan sedang, dan tidak ada responden yang memiliki tingkat pengetahuan rendah $(0 \%)$.

Hasil analisa univariat didapatkan nilai mean 22,36 yang menunjukkan secara umum tingkat pengetahuan responden berada pada kategori tingkat pengetahuan tinggi, dengan median 23 dan modus 23 pada tingkat pengetahuan tinggi.

2. Distribusi frekuensi perkembangan motorik kasar

Variabel perkembangan motorik kasar terbagi dalam dua kategori yaitu perkembangan baik dan perkembangan kurang baik.

Tabel 2. Distribusi Frekuensi Perkembangan Motorik Kasar Anak Usia 1 - 5 tahun di Posyandu Mekarsari Banjarsari

\begin{tabular}{ccc}
$\begin{array}{c}\text { Perkembangan } \\
\text { Motorik Kasar }\end{array}$ & $\mathrm{F}$ & $\%$ \\
\hline Baik & 47 & $71,21 \%$ \\
\hline Kurang Baik & 19 & $28,79 \%$ \\
\hline Jumlah & 66 & $100 \%$ \\
\hline
\end{tabular}

Berdasarkan tabel di atas dapat dicermati bahwa dari 66 anak, yang memiliki perkembangan motorik kasar dengan kategori baik lebih banyak yaitu 47 anak
$(71,21 \%)$ dibandingkan dengan anak yang memiliki perkembangan motorik kasar kurang baik yaitu 19 anak $(28,79 \%)$.

3. Hubungan antara tingkat pengetahuan ibu tentang stimulasi perkembangan dan perkembangan motorik kasar

Dari hasil uji Chi-Square program SPSS versi 16.0 dengan $\alpha=5 \%$ (0.05) diperoleh $p$ sebesar 0.005 sehingga nilai $\mathrm{p}<0.05$, yang berarti $\mathrm{H}_{0}$ ditolak dan $\mathrm{H}_{\mathrm{a}}$ diterima sehingga ada hubungan antara tingkat pengetahuan ibu tentang perkembangan motorik kasar dengan perkembangan motorik kasar pada anak usia 1 - 5 tahun di posyandu Mekarsari.

\section{PEMBAHASAN}

1. Tingkat Pengetahuan

Pengetahuan ibu tentang stimulasi perkembangan meliputi pengertian, manfaat, waktu yang tepat untuk memberikan stimulasi dan cara melakukan stimulasi perkembangan. Dengan menggunakan tes kognitif berupa kuesioner didapatkan hasil responden dengan tingkat pengetahuan tinggi sebanyak 55 orang $(83,33 \%)$, tingkat pengetahuan sedang sebanyak 11 orang $(16,67 \%)$ dan tingkat pengetahuan rendah tidak ada. Sehingga dapat diketahui bahwa sebagian besar ibu di Posyandu Mekarsari Kecamatan Banjarsari memiliki tingkat pengetahuan tinggi yaitu sebanyak 55 orang (83,33\%).

Menurut Erfandi (2009), ada beberapa faktor yang bisa mempengaruhi tingkat pengetahuan seseorang diantaranya adalah tingkat pendidikan, usia, media informasi 
seperti televisi, majalah, tabloid, buku, dan lingkungan.

Pada penelitian ini, sebagian besar responden memiliki tingkat pengetahuan yang tinggi tentang stimulasi perkembangan. Kondisi tersebut dimungkinkan terjadi karena dengan melihat tingkat pendidikan ibu sebagian besar pada tingkat pendidikan SMA yaitu 46 orang $(69 \%)$ bahkan ada 4 (empat) ibu (6,06\%) dengan latar belakang pendidikan Diploma dan ada 1 (satu) ibu $(1,51 \%)$ dengan latar belakang pendidikan S1. Dari seluruh responden hanya sebagian kecil dengan latar belakang pendidikan SD yaitu 3 (tiga) orang (4,55\%). Dengan tingkat pendidikan responden tersebut mempengaruhi kemampuan responden dalam memahami pengetahuan yang diperoleh termasuk pengetahuan berkaitan dengan stimulasi perkembangan pada anak. Hal ini sesuai dengan pernyataan yang disampaikan oleh Erfandi (2009), yang mengungkapkan bahwa pendidikan merupakan suatu alat yang dapat dipakai untuk memperbaiki dirinya dalam melangsungkan kehidupan bermasyarakat. Semakin tinggi tingkat pendidikan semakin tinggi pula tingkat pengetahuan akan kesehatan, sebaliknya pendidikan yang rendah kemungkinan akan mempengaruhi tingkat pengetahuan seseorang.

Selain dari faktor pendidikan, jika dilihat dari faktor usia dapat dilihat bahwa keseluruhan responden berada pada kategori usia dewasa muda (20 - 40 tahun) dan dewasa menengah (41 - 46 tahun). Dengan kategori usia dewasa tersebut memungkinkan responden untuk memiliki daya tangkap dan pola pikir yang lebih baik khususnya mengenai kesehatan pada anak dan faktor faktor yang mempengaruhi perkembangan anak. Hal ini sesuai dengan apa yang disampaikan oleh Erfandi (2009), bahwa usia juga berpengaruh terhadap daya tangkap dan pola pikir seseorang. Semakin bertambah usia semakin berkembang pula daya tangkap dan pola pikirnya, sehingga pengetahuan yang diperoleh semakin baik.

Berdasarkan analisa yang dilakukan oleh peneliti, tingginya tingkat pengetahuan sebagian besar responden mengenai stimulasi perkembangan juga bisa dikarenakan adanya informasi yang didapatkan ibu melalui tayangan televisi dimana dengan perkembangan IPTEKS sekarang ini hampir seluruh lapisan masyarakat bisa memperoleh informasi kesehatan dari televisi dengan mudah. Disamping dari televisi ibu juga bisa mendapatkan informasi dari media lain yang bisa diperoleh dengan mudah di masyarakat seperti majalah dan tabloid. Selain informasi yang diperoleh secara pribadi tersebut, informasi juga bisa didapatkan pada saat ibu melakukan kegiatan posyandu. Hal tersebut yang mungkin bisa mempengaruhi sebagian besar tingkat pengetahuan ibu tentang stimulasi perkembangan dalam kategori tinggi.

2. Perkembangan Motorik Kasar Perkembangan motorik kasar menurut Soetjiningsih dan Ranuh (2014), merupakan aspek perkembangan lokomosi (gerakan) dan postur (posisi tubuh) dimana prinsip perkembangan motorik diantaranya memiliki pola 
perkembangan yang dapat ditentukan dan kecepatan perkembangan berbeda untuk setiap individu. Dalam penelitian ini perkembangan motorik kasar pada anak diukur menggunakan formulir DDST yaitu merupakan salah satu dari metode skrining terhadap kelainan perkembangan anak yang meliputi 4 (empat) aspek penilaian yaitu aspek personal sosial, gerakan motorik halus, bahasa, dan gerakan motorik kasar. (Djafar, 2005)

Dalam penelitian ini perkembangan anak yang dinilai hanya pada aspek gerakan motorik kasar. Penilaian dilakukan dengan menentukan umur anak terlebih dahulu kemudian ditarik garis berdasarkan umur kronologis yang memotong garis horizontal tugas perkembangan pada formulir DDST. Berdasarkan data pada tabel 1.2. mengenai perkembangan motorik kasar pada 66 anak usia 1 - 5 tahun di Posyandu Mekarsari Kecamatan Banjarsari menunjukkan bahwa lebih banyak anak yang mengalami perkembangan baik yaitu 47 anak $(71,21 \%)$ dibanding dengan anak yang mengalami perkembangan kurang baik yaitu 19 anak (28,79\%). Demikian juga dari hasil uji stastistik untuk perkembangan motorik kasar menunjukkan bahwa modus adalah pada perkembangan yang baik dengan jumlah 47 anak.

Secara umum terdapat 2 (dua) faktor utama yang mempengaruhi tumbuh kembang anak yaitu faktor genetik dan faktor lingkungan. Dalam penelitian ini anak - anak yang mengalami kelainan genetik tidak dipakai sebagai responden demikian juga anak yang mengalami kelainan tonus otot atau penyakit neuro muskuler sehingga faktor yang mempengaruhi perkembangan motorik pada anak dalam penelitian ini hanya dilihat dari faktor lingkungan. Faktor lingkungan yang bisa mempengaruhi tumbuh kembang anak meliputi faktor gizi, kondisi lingkungan anak, pengasuhan orang tua, dan stimulasi dini. (Eveline dan Djamaludin, 2010) Demikian juga perkembangan motorik kasar yang dialami oleh anak dalam penelitian ini bisa dipengaruhi oleh salah satu atau beberapa faktor lingkungan di atas. Diantara faktor - faktor di atas, salah satu faktor lingkungan yang memiliki peranan besar dan sangat mempengaruhi perkembangan motorik pada anak adalah adanya stimulasi. Stimulasi dari lingkungan merupakan hal yang sangat penting, anak yang mendapat stimulasi yang terarah dan teratur akan lebih cepat berkembang dibanding kan dengan anak yang kurang / tidak mendapat stimulasi. (Soetjiningsih dan Ranuh, 2014)

3. Hubungan antara tingkat pengetahuan lbu tentang stimulasi perkembangan dan perkembangan motorik kasar

Dari hasil uji Chi-Square program SPSS versi 16.0 dengan $\alpha=5 \%$ $(0,05)$ diperoleh $p$-value sebesar 0,005 sehingga nilai $p<0,05$ yang berarti $\mathrm{Ho}$ ditolak dan $\mathrm{H}_{a}$ diterima sehingga ada hubungan tingkat pengetahuan tentang stimulasi perkembangan dengan perkembangan motorik kasar pada anak usia $1-5$ tahun di Posyandu Mekarsari Kecamatan Banjarsari.

Berdasarkan hasil Pearson Chi Square diperoleh nilai positif 7,819 yang menunjukkan ada korelasi positif sehingga dapat 
disimpulkan bahwa semakin tinggi tingkat pengetahuan ibu tentang stimulasi perkembangan maka perkembangan motorik kasar pada anak semakin baik dan sebaliknya semakin rendah tingkat pengetahuan ibu tentang stimulasi perkembangan maka perkembangan motorik kasar pada anak semakin kurang baik. Hal tersebut dapat terjadi karena responden yang mempunyai pengetahuan yang tinggi tentang stimulasi perkembangan memungkinkan akan bersikap baik dan mendukung pentingnya pemberian stimulasi perkembangan pada anak sejak dini, dan dengan sikap tersebut maka akan mempengaruhi responden untuk memberikan stimulasi perkembangan pada anak dengan waktu dan cara yang tepat. Hal ini sesuai dengan proses adopsi perilaku yang dikemukakan oleh Notoatmodjo (2007), bahwa proses adopsi perilaku dimulai dari seseorang menyadari arti dari sebuah stimulus (objek), mulai tertarik kepada stimulus dan mulai menimbang-nimbang baik dan tidaknya stimulus tersebut bagi dirinya, lalu mulai mencoba perilaku baru dan akhirnya berperilaku baru sesuai dengan pengetahuan, kesadaran, dan sikapnya terhadap stimulus.

Dengan melihat teori yang disampaikan oleh Notoatmodjo tersebut dimungkinkan responden dalam penelitian ini juga telah melakukan pemberian stimulasi pada anak oleh karena responden telah memiliki pengetahuan yang benar mengenai pemberian stimulasi pada perkembangan anak. Hal ini bisa dilihat dari sebagian besar responden $(98,5 \%)$ membenarkan bahwa stimulasi merupakan kegiatan orangtua dalam memberikan rangsangan yang dilakukan sedini mungkin, sebagian besar responden juga sudah mengetahui bahwa cara yang tepat dalam memberikan stimulus pada anak yaitu dengan mengajak anak bermain yang ditunjukkan dengan $97 \%$ responden membenarkan bahwa bermain bersama anak dalam suasana yang menyenangkan dan penuh kasih sayang akan jauh lebih efektif dalam memberikan stimulasi pada anak. Hal ini sesuai dengan yang disampaikan oleh Soetjiningsih dan Ranuh (2014), bahwa memberikan suasana yang kondusif yaitu menciptakan lingkungan yang wajar, santai dan menyenangkan, dalam suasana bermain, bebas dari tekanan dan hukuman akan memacu anak untuk belajar sambil bermain termasuk dalam mempelajari gerakan - gerakan motorik kasar.

Berdasarkan analisa dari peneliti, dengan pengetahuan yang benar yang telah dimiliki oleh responden mengenai stimulasi perkembangan pada anak maka mempengaruhi munculnya perilaku yaitu pemberian stimulasi pada anak sehingga sebagian besar anak dari ibu yang memiliki tingkat pengetahuan yang tinggi di Posyandu Mekarsari memiliki perkembangan motorik kasar yang baik, namun demikian pada ibu yang memiliki tingkat pengetahuan yang tinggi juga masih ditemukan ada 12 anak yang mengalami perkembangan motorik kasar yang kurang baik, hal ini mungkin dipengaruhi faktor - faktor lain yang tidak dibahas secara mendalam dalam penelitian ini.

Hasil penelitian ini juga telah dibuktikan oleh Sari, Andayani, dan Salafas (2012), pada 
penelitiannya yang berjudul "Hubungan Pengetahuan dan Sikap lbu dengan Perkembangan Motorik Kasar anak usia 3-5 tahun di PAUD Ngudi Rahayu Desa Lerep Kecamatan Ungaran Barat Kabupaten Semarang". Hasil penelitian menunjukkan nilai $p$-value sebesar $0,007<0,05$ berarti ada hubungan antara pengetahuan ibu dengan perkembangan motorik kasar anak usia 3-5 tahun. Demikian juga pada responden dalam penelitian ini, dengan tingkat pengetahuan yang tinggi tentang stimulasi perkembangan maka memungkinkan responden untuk berperilaku memberikan stimulasi pada perkembangan motorik kasar dengan benar sehingga anak memiliki perkembangan motorik kasar yang baik.

\section{KESIMPULAN}

Berdasarkan hasil penelitian dengan judul "Hubungan Tingkat Pengetahuan lbu tentang Stimulasi Perkembangan dengan Perkembangan Motorik Kasar pada Anak Usia 1 - 5 Tahun di Posyandu Mekarsari Nayu Timur Banjarsari" dapat diperoleh kesimpulan sebagian besar ibu memiliki tingkat pengetahuan tinggi tentang stimulasi perkembangan yaitu sebanyak 55 orang $(83,33 \%)$, lebih banyak anak yang mengalami perkembangan motorik kasar baik yaitu 47 anak $(71,21 \%)$ dibanding dengan anak yang mengalami perkembangan motorik kasar kurang baik yaitu 19 anak (28,79\%). Dan dari hasil uji Chi-Square program SPSS versi 16.0 dengan $\alpha=5 \%(0.05)$ diperoleh $p$ sebesar 0.005 sehingga nilai $p<$ 0.05 , yang berarti $\mathrm{Ho}$ ditolak dan $\mathrm{H}_{\mathrm{a}}$ diterima sehingga ada hubungan antara tingkat pengetahuan ibu tentang stimulasi perkembangan dengan perkembangan motorik kasar pada anak usia $1-5$ tahun di Posyandu Mekarsari Banjarsari.

\section{SARAN}

Puskesmas perlu lebih meningkatkan penyuluhan mengenai stimulasi perkembangan dan meningkatkan peran kader posyandu dalam penyebarluasan informasi mengenai pentingnya stimulasi perkembangan pada anak, serta perlu ada penelitian selanjutnya yang berkaitan dengan hubungan status gizi pada anak dengan perkembangan anak

\section{DAFTAR PUSTAKA}

Ariani, Ayu Putri. Aplikasi Metodologi Penelitian Kebidanan dan Kesehatan Reproduksi. Yogyakarta : Nuha Medika, 2014.

Erikania, Julie. Nakita Panduan Tumbuh Kembang Anak. Jakarta : Sarana Bobo, 2008.

Eveline dan Nanang Djamaludin. Panduan Pintar Merawat Bayi dan Balita. Jakarta: Wahyu Media, 2010.

Hidayat, Aziz Alimul. Metodologi Penelitian Keperawatan dan Teknik Analisis Data. Jakarta: Salemba Medika, 2009.

- Riset Keperawatan dan Teknik Teknik Penulisan IImiah. Jakarta: Salemba Medika, 2008.

Pengantar IImu Kesehatan Anak untuk Pendidikan Kebidanan. Jakarta Salemba Medika, 2009. 
Lerin, Christine. 105 Permainan untuk Meningkatkan Kecerdasan dan Kreativitas Buah Hati. Jakarta : Trans Media, 2009.

Notoatmodjo, Soekidjo. Promosi Kesehatan dan IImu Perilaku. Jakarta: Rineka Cipta, 2007.

Sunaryo. Psikologi untuk Keperawatan. Jakarta : EGC, 2004.

Suyanto. Metodologi dan Aplikasi Penelitian Keperawatan. Yogyakarta: Nuha Medika, 2011.

Soetjiningsih dan Ig. N. Gde. Ranuh. Tumbuh Kembang Anak. Edisi 2. Jakarta: Penerbit Buku Kedokteran EGC. 2014.

Wawan, A dan Dewi M. Teori dan Pengukuran Pengetahuan Sikap Dan Perilaku Manusia. Yogyakarta: Nuha Medika, 2011.

Aprilina, Marisa. Hubungan Tingkat Pengetahuan lbu tentang Stimulasi Kinetik dengan Tingkat Perkembangan Motorik Kasar Anak Usia Prasekolah (3-5 Tahun) di Desa Pucangrejo Wilayah Kerja Puskesmas Gemuh Kendal. Skripsi. Semarang : UNIMUS, 2006.

Erfandi. Pengetahuan dan FaktorFaktor yang Mempengaruhi. 2009.
Gunawan, Gladys, Eddy Fadlyana, dan Kusnandi Rusmil. Hubungan Status Gizi Dan Perkembangan Anak Usia 1-2 Tahun. 2011.

Jafar, Nurhaedar. Pertumbuhan dan Perkembangan. Tesis. Makasar: Fakultas Kesehatan Masyarakat Universitas Hasanuddin, 2005.

Sari, Puspitasari, Ari Andayani, dan Eti Salafas. Hubungan Pengetahuan dan Sikap Ibu dengan Perkembangan Motorik Kasar Anak Usia 35 Tahun di PAUD Ngudi Rahayu Desa Lerep Kecamatan Ungaran Barat Kabupaten Semarang. Tesis. Semarang: Akademi Kebidanan, 2012.

1 Dosen AKPER Panti Kosala Surakarta

2 Mahasiswa AKPER Panti Kosala Surakarta

3 Mahasiswa AKPER Panti Kosala Surakarta 